POLISH POLITICAL SCIENCE

VOL XXXVII 2008

PL ISSN 0208-7375

\title{
THE QUESTION OF KOSOVO INDEPENDENCE IN POLISH POLITICAL DEBATE
}

\author{
by Renata Podgórzańska
}

The proclamation of independence of Kosovo, although expected, had a destabilizing impact on the international situation. International community had various opinions on the decision of Kosovo authorities. ${ }^{1}$ Numerous conditions influenced the positions of individual countries. Countries acknowledging independence of Kosovo, that is some EU countries and the United States, recognized the proclamation of independence of Kosovo as a final stage of the Yugoslavia's break-up with the basis for peaceful cooperation on the Balkans. Whereas, countries opposing the secession of Kosovo found it against the international law. They perceived this act as an example of western countries' dominance and feared that it would form a dangerous precedent threatening international stability and security. ${ }^{2}$

1 Kosovo authorities paid no heed to the suggestions of Brussels encouraging to postpone the decision on independence until Serbia and Kosovo were admitted to the European Union. Their position, to a large extent was influenced by a failure in the attempts of the international community concerning the Kosovo status. See A. Balcer, W. Górecki, M. Kaczmarski, R. Sadowski, W. Stanisławski, Kosowo Proclaims Independence, "Best - Weekly OSW", No. 41, 20.02.2008, http://osw.waw.pl/pub/BiuletynOSW/2008/0802/080220/best01.htm

2 On 17 February 2008 the Parliament of Kosovo passed a 12 point-declaration of independence during a special session (boycotted by 11 Serbian representatives). See: Kosova Declaration of Indipendance, http://www.assembly-kosova.org/common/docs/declaration_indipendence.pdf 
Considering the reasons of the Kosovo's secession, irrespective of political, legal and moral aspects of this decision, its potential outcomes shall be emphasized ${ }^{3}$. Those consequences shall be examined with respect to many planes. On the one hand there is a significant influence of this decision on the international situation in terms of the European security and development of international cooperation, whereas on the other hand we shall emphasize its influence on bilateral relations between Serbia and countries acknowledging the Kosovo's secession. ${ }^{4}$ Positions of individual European and non-European countries referring to that part of the Balkans depend on many factors including political, economic and commercial aspects, as well as the so far existing relations with Serbia, geographic location, and plans and concepts of their own foreign policy.

Countries opposing the Kosovo's secession reported numerous arguments including incompatibility of the proclamation of independence of Kosovo with international law and resolutions of the Helsinki conference on inviolability of state borders in Europe as well as a conflict with the Serbian internal law. Additionally, they emphasized the possibility of forming a precedent for other nations striving for independence. ${ }^{5}$ Moreover, they raised the question of destabilization of states which put much effort to build their identity after the break-up of Yugoslavia. ${ }^{6}$ Unstable political situation, economic weakness and problems stemming from ethnic and religious variety

${ }^{3}$ See A. Balcer, M. Kaczmarski, W. Stanisławski, Kosovo - Before a Final Resolution. The Process of Regulating International Status-Political and Historical Conditions, Prospects of the situation Development, "Works of the Eastern Studies Center", journal 27, Warsaw February 2008, http://osw.waw.pl/pub/prace/27/prace27.htm; K. Pawłowski, Kosovo. Conflict and intervention, Lublin 2008; M. Waldenberg, Break-up of Yugoslavia. Yugoslavian Mirror of the International Politics, Warsaw 2005; S. Wojciechowski, Integration and Disintegration of Yugoslavia in the Turns of XX and XXI Centuries, Poznan 2002; S. Wojciechowski, Conflict in Kosovo, [in:] Feuds and Conflicts. Legal and Political Aspects, (ed.) W. Malendowskiego, Poznań 2000.

${ }^{4}$ Acknowledging of Kosovo independence did not mean automatic establishing of diplomatic relations.

5 See: Armed Conflicts in the Post Soviet Area. Current Condition. Prospects for Regulations. Consequences, "Works of the Eastern Studies Center", Journal no 9, June 2003; M. Topczewska, National Separatisms in the Eastern Europe, "European Studies" 2001, No. 1.

6 The operation of Bosnia and Hercegovina may be put at stake. Serbs residing that country being to a great extent independent from the government in Sarajevo announced the possibility of the secession from the federal Bosnia (under the regulation concluded in Deyton Bosnia and Hercegovina consist of two elements, that is Federation of Bosnia and Hercegovina and the Republic of Serbia). The situation was exacerbated by the parliament of Bosnian Serbs who adopted a resolution which stated the possibility of organizing a referendum concerning separating the Republic of Serbia from Bosnia and Hercegovina. See: A. Skieterska, Serbs in Bosnia Demand Independence, "Gazeta Wyborcza", 23-24.02.2008. 
provoked "chain reaction" in the region. Future relations of the independently operating country with neighboring countries as well as its stability and internal security (especially with reference to Serbs domiciled in Kosovo) were also an issue. ${ }^{7}$

International disagreement over the question of independence of Kosovo was reflected in Poland and attracted many varied comments. There were vigorous opponents to Poland's acknowledgement of the independence of Kosovo, adherents of withholding any decisions until the situation „cleared out” as well as strong supporters of independence of Kosovo. There were also advocates of the position that Poland without any direct interests in the region did not have any obligation to be interested in that question as it could not expect any benefits. ${ }^{8}$ Supporters of independence of Kosovo raised arguments referring to the year 1989 and Poland's regaining independence. Thus, they pointed out to the need of supporting Kosovian striving for independence. The completion of the transformation process on the Balkans with independence of Kosovo was to crown the break-up of Yugoslavia. The right of nations to be independent was raised, historical justice was referred to and even it was emphasized that nobody had found a more effective way to reconcile two feuding nations. It was underlined that Poland should take into consideration the position of the EU and NATO while reaching its decision reflecting the European policy.

Opponents of acknowledgement of Kosovo's secession pointed out to potential consequences of the independence of Kosovo with regard to security in the region and bilateral relations between Poland and Serbia. They warned against "submissive" support of the policy of the EU and US for the pure sake of solidarity. They encouraged to undertake an independent decision steered only by the sense of responsibility for European security.

The position of Poland with regard to the independence of Kosovo shall be considered in two aspects. Firstly, consequences of acknowledging the independence of Kosovo by Poland with regard to security and stability in that region shall be considered and secondly, the position of problems on the Balkans in the Polish foreign policy shall be analyzed. Analyzing Polish foreign policy implemented after 1989 it is evident that the Balkan problems had a marginal position among its priorities. The Balkan region incidentally appeared in the principles of Polish foreign policy and if it happened, discussed issues referred to the problem of security in Europe and the process of EU enlargement. Due to the fact that our strategic interests are focused in

7 J. Kumoch, M. Janik, Serbs Fear a Revenge, “Dziennik”, 19.02.2008.

8 Por. J. Haszczyński, Caution with Kosovo, "Rzeczpospolita”, 23.02.2008; M. Piłka, Unfit for Independence, "Rzeczpospolita”, 19.02.2008; P. Reszka, Kosowo - sad independence, "Dziennik", 19 II 2008; B.R. Zagórski, Kosovo Should Be Educated, "Dziennik", 19.02.2008; P. Świeboda, Kosovo, Conscience of the Union, "Gazeta Wyborcza”, 23-24.02.2008. 
the Euro-Atlantic area and the Central and Eastern Europe Poland engaged its forces and means to meet requirements concerning foreign policy in that region. The secondrate role of the Balkans in Polish foreign relations does not determine however the interest of Poland in the development of situation in that region. Issues concerning the Balkan region were touched upon while discussing basic priorities for Polish foreign policy. Interest in the Balkan region stems from the relationship between Polish foreign policy priorities and the situation in the international arena. Factors determining foreign policy of each country (both internal and external) condition effectiveness of the country's operation in the international arena and implementation of its vital interests. ${ }^{9}$ The situation did not change when basic aims of Polish foreign policy were accomplished, that is when Poland was admitted to NATO and EU. Although debates concerning Polish foreign policy in new geopolitical conditions have been initiated, problems concerning the Balkan region are still of minor interest.

Analyzing circumstances of independence of Kosovo proclamation we shall bear in mind the fact that whether or not Poland acknowledges independence of Kosovo it does not exert any major impact on the development of the situation on the Balkans. Poland's attitude is rather more important for Polish political scene than it is for Kosovo or Serbia. The statement of Mr. Adam Daniel Rotfeld, former Minister of Foreign Affairs "I am of the opinion that if Poland withheld acknowledging independence of Kosovo, nobody in the world, apart from us would even notice that"10. That statement reflects significance of our position for the Balkan affairs. The secondrate influence of the position of Poland on the Balkan issues does not, however, prevent us from presenting our opinion on those issues and events taking place on the international arena. Lack of direct impact of Poland's position on the situation in that region does not mean Poland's isolating from that region. There are a number of factors determining our position in that aspect. Poland as a NATO and EU member has certain commitments to fulfill. One of them is providing Polish servicemen

9 See: E. Cziomer, Position of Poland in the International Relations, [in:] International Political Relations, E. Cziomera (ed.), Krakow 2008, pp. 405-412; R. Łoś, Theory on International Relations. Selected aspects, Łódź 2001, p. 30; R. Kupiecki, K. Szczepanii, Foreign Policy of Poland 1918-1994, Warsaw 1995, p. 10; R. Łoś, Theory on International Relations. Selected Aspects, Łódź 2001, p. 30-35; W. Malendowski, New Conditions and Aims of Polish Foreign Policy After 1989, [in:] Poland and its Neighbours in the Nineties. Political and Economic Aspects of Cooperation and Integration, B. Łomiński, M. Stolarczyk (ed.), Katowice 1998, p. 13; Z.J. Pietraś, Foreign Policy of the Country, [in:] T. Łoś-Nowak, Current International Relations, Wrocław 1995, pp. 54-62; R. Zięba, Conditions of Foreign Policy, [in:] J. Kukułka, R. Zięba, Foreign Policy of the Country, Warsaw 1992, pp. 35-51.

${ }^{10} \mathrm{~J}$. Przybylski, Polish Representatives Should Calm Anger of Serbs as soon as possible, "Rzeczpospolita", 27.02.2008. 
and policemen to that region. If only for that reason we should be interested in the development of the situation in that region"1. We shall also bear in mind that a new country will depend economically, to a large extent, on the assistance of the international community, including EU. Thus, Poland, as an EU member country shall bear certain costs related to the operation of that country. The Kosovo's secession will certainly influence the level of security in the region and the situation on the international arena. Thus, even those aspects shall justify our interest in the question of proclamation of Kosovo independence and future peaceful operation of that country.

We should take a closer look at the way Polish diplomacy justified the decision on acknowledging the independence of Kosovo, its arguments and goals which it mentioned could be achieved at that occasion. The position of parliamentary and nonparliamentary opposition is important in that aspect. It is worth paying attention to their position not only in respect to the question of independence of Kosovo but also to the way they evaluated the operation of the government. We shall remember that especially non-parliamentary parties do not have many occasions to present their views to public opinion. The event in question formed an occasion to demonstrate their positions and remind electors about their existence. Parties use such situations to achieve their own goals. Not only the interests of the cause are taken into consideration. Parties without budget funds and forgotten politicians perceive organizing manifestations, the Internet actions, and writing blogs as the only chance to appear in public, remind electors about their existence or come into view in media' ${ }^{12}$.

Considering the position of Poland with respect to independence of Kosovo we shall pay attention to the so far implemented Polish policy towards the situation on the Balkans and primarily to the Kosovo issue ${ }^{13}$. Current lack of agreement with concern to basic issues of Polish foreign policy as well as disagreement referring to its form, character and ways of implementation was reflected in a public debate referring to the issue of independence of Kosovo. Two basic stands could be noticed. One came down to acting with caution and restraining from operations that could have a negative impact on the situation on the Balkans. The President supported that position and encouraged not to take any hasty decisions as well as to evaluate potential costs that Poland might bear acknowledging independence of Kosovo. Whereas, the

11 Soon after the independence was announced there were several incidents in Mitrovica, Polish and Ukrainian policemen protecting the premises of UN court suffered.

${ }_{12}$ See: J. Cieśla, The Sofa for the Rejected, www.polityka.pl/polityka/index.jsp?place=Lead33\&news_cat_id=933\&news_id=249289\&layout=18\&forum_id=14577\&fpage=Threads\&page $=$ text

${ }_{13}$ See: M. Waldenberg, The Issue of Kosovo and the Position of Poland, "A Yearbook of Polish Foreign Policy 2000", Warszawa 2000, pp. 245-258. 
Minister of Foreign Affairs, Mr. Radosław Sikorski, was in favor of unhesitating in acknowledging the independence of Kosovo.$^{14}$ The intention of the Minister was for Poland to be one of the first countries to acknowledge the independence of Kosovo. Simultaneously, he emphasized that the Kosovo issue cannot constitute a precedent for other nations ${ }^{15}$. The only decisive factor for Poland's decision was the stand of the European Union. The Minister emphasized that agreement and common will of the EU member countries were crucial in that case. However, diversity in opinions among the EU member countries prevented the issue to be settled within a short period of time. In relation to various interests of the EU member countries and diversified attitudes to the question of independence of Kosovo they did not present uniform positions. Only after longer negotiations did they manage to assume a common stand on that issue ${ }^{16}$. In Brussels, during the meeting of ministers of foreign affairs it was stated that "each country in line with national practice and rules of law as well as in accordance with the international law, may establish relations with Kosovo as an independent country under international supervision." ${ }^{17}$ What is most important, EU member countries emphasized that "it is a unique case and it shall not constitute a precedent for other countries or regions." ${ }^{18}$ The purpose of such wording was to dissipate doubts of EU member countries, which due to strong separatist tendencies on their own territories were opposed to the independence of Kosovo and announced that they would not acknowledge the independence of the new state. Such countries as Spain (Basques and Catalans) and Romania (Hungarian minority in Transylvania) were afraid of potential future referring to the Kosovo precedent.

The question of acknowledging the independence of Kosovo by Poland seemed not to be an issue, what was important was the moment Poland would do that. After the meeting in Brussels the Minister of Foreign Affairs declared that he would submit the motion for acknowledging the independence of Kosovo on the next session of the government planned for $19^{\text {th }}$ February. He hoped that the Council of Ministers would support his position. However, in relation to arising disagreement over that issue between the government and the President it was decided to postpone the final

${ }^{14}$ It was pointed out to him that in its time he warned against Islamization of Kosovo See: Sikorski 9 Months Ago: Kosovo for Wahhabi Money, http://wiadomosci.gazeta.pl/Wiadomosci/1,80708,4955365.html; "Journal from the seating of the Foreign Affairs Committee", Seym of the Republic of Poland V term, 29.05.2007.

15 Sikorski Appeals for Independence of the Province, http://www.tvn24.pl/-1,1539303, wiadmomosc.html

16 D. Pszczółkowska, EU Splits Kosovo, “Gazeta Wyborcza”, 29.02.2008.

17 Tomorrow Poland is going to acknowledge the independance of Kosovo, http://www. tvn24.pl/-1,1539303, wiadomosc.html

18 D. Pszczółkowska, EU splits Kosovo, op.cit. 
decision concerning that issue. The opinion of the President, Mr. Lech Kaczyński turned out to be determining. He explicitly expressed his discontentment with haste concerning the acknowledgement of independence of Kosovo by the government of Poland and it was upon his request that the decision on Kosovo issue was postponed. ${ }^{19}$ The Prime Minister intending to consult the issue with the President and gain an understanding of his arguments decided to postpone the deadline to reach the decision. The President argued that the government should withhold acknowledging independence of Kosovo until potential benefits and costs that Poland would have to cover were estimated. He was afraid that the independence of Kosovo would constitute a dangerous precedent for separatist provinces in Georgia (Abkhasia, Southern Osetia) or Moldavia (Dniester Republic). Quoting postulates of Polish western partners that is Georgia and Ukraine, which counted on Poland's circumspection with regard to that issue, there was a pressure to postpone the decision..$^{20}$ Simultaneously, it was emphasized that the position of the President by no means equaled with withholding the decision on acknowledging the independence of Kosovo. Moreover, the delay was not supposed to mean that the President was against the independence of that province.

It is worth noticing that not only opposition parties appealed for the delay. Some politicians of the Civic Platform Party also encouraged to apply reserve and detachment from the matter. Mr. Bronisław Komorowski, for instance, stated that there was no sense in "stepping out first" suggesting that the government should withhold its decision. ${ }^{21}$ Whereas, Mr. Bogusław Sonik, other politician of the Civic Platform Party mentioned inspiring European separatists. He emphasized that the situation should be analyzed from two aspects, that is from the point of view of Kosovo as well as from the point of view of Serbia. ${ }^{22}$ Mr. Władysław Bartoszewski was very cautious to discuss the Kosovo question. He stated "I sympathize emotionally with countries which emancipate themselves" however, he mentioned that Kosovo "is a two million country with no industry or infrastructure and with a tremendous unemployment". In his opinion such a situation posed a threat to its existence in the future. At the same time, lack of belief in the possibility of Kosovo's independent political and economic operation should not prevent us from acknowledging its independence. In that respect Poland should "follow other countries of the European Union." ${ }^{23}$ It

19 D. Kublik, M. Olejnik, Tusk: The Constritution Should be Altered, "Gazeta Wyborcza”, 20.02.2008.

20 P. Zychowicz, Polish Debate on Kosovo, "Rzeczpospolita”, 20.02.2008.

21 A. Wojciechowska, No Decision Concerning Kosovo, “Dziennik”, 20.02.2008.

22 Ibidem.

${ }^{23}$ Bartoszewski, "Does Not See” the Life in Kosovo, http://wiadomości.onet.pl/1699621,12, item.html 
meant that acknowledging the independence of Kosovo could exert a negative impact on relations with Russia which was opposed to the secession.

In spite of the disparate opinion of the President, pressure exerted by some parties and social and political organizations, on 26th February the Government adopted the resolution on acknowledging the independence of Kosovo. However as the Prime Minister Mr. Donald Tusk emphasized, the government was "grateful to the President for dissociating the government from the existing situation in the right time". In the opinion of the Prime Minister it was good that the decision was not announced fast, in an ostentatious way, as the delay made it "more reserved, gentle and understandable for the world". Stating that "it was good that there was a dialogue between the Prime Minister and the President" he did not conceal that all the credits for that should go to the latter. ${ }^{24}$ For Poland, as many times emphasized by the Prime Minister and the Minister of Foreign Affairs it was important to become visible in the European policy concerning Kosovo. This pro-Europe attitude of Poland, in the opinion of Mr. Donald Tusk, meant "forming together a common European decision in cooperation with our most important allies including the USA", as well as "work for forming a European perspective for countries of that region including Kosovo and Serbia." ${ }^{25}$ The European solidarity was expressed in the adopted resolution. It was emphasized that Poland acknowledging the independence of the Republic of Kosovo "strengthens solidarity with other EU member countries and the international community as well as supports peaceful social and political transformation of the Western Balkans, and expresses its hope that independent Kosovo will make a good partner to develop valuable political, economic and social relations."26

The Decision on acknowledging Kosovo was not, however, "unconditional". As the Minister of Foreign Affairs emphasized "from now on Poland will demand more from Kosovo" ${ }^{27}$. Poland expected primarily that the new country would observe the provisions of the independence declaration which defined the character of the country as secular and democratic, emphasized respecting national and social minorities and mentioned the importance of protecting cultural heritage. Additionally, it was emphasized that the decision on acknowledging the independence of

${ }^{24}$ A. Szostakiewicz, The Government Acknowledged the Independance of Kosovo, http:// www.psz.pl/content/view/9135/

25 The President and the Prime Minister on the Independance of Kosovo, http://wiadomosci.onet.pl/1695179,11,item.html

26 The Resolution on Acknowledging the Independence of the Republic of Kosovo by the Republic of Poland Submitted by the Minister of Foreign Affairs, http://www.kprm.gov.pl/s. php? doc $=1271$

27 Sikorski: There Could Not Be Other Decision, http://www.tvn24.pl/0,1540243,wiadomosc.html 
Kosovo was not the easiest one. Friendly relations which had for years existed between Poland and Serbia made the decision very difficult. Poland was afraid that acknowledging the independence of Kosovo the relations between Poland and Serbia could deteriorate. Simultaneously, Poland did not intend to be perceived as hostile. Thus, an idea appeared to send to Serbia a special political mission, the purpose of which would be to convince Serbs of Polish sympathies. As the Prime Minister explained the intention was to admit in the future both Serbia and Kosovo to the European Union, and convince Serbia that it had supporters and allies also in the European Union. In the opinion of the Prime Minister "Serbs should not be harmed. They deserve more concern and attention". Thus, Serbs should have the conviction that „within the European Union there are countries, as for instance Poland, which are willing to support Serbia if it is interested in such a European perspective." ${ }^{28}$

Coalition politicians justified acknowledging the independence of Kosovo as the need to accept the inevitable. Certain delay in reaching the decision caused by the resistance of the head of state only confirmed propriety of the decision. It was pointed out that the position of Poland was to reflect EU policy in that respect and to reflect the decision of most European countries which accepted that fact. Mr. Grzegorz Dolniak, vice chief of the Civic Platform Party emphasized that it was important that the decision was reached „after a certain period of reflection” and Poland was not "the first country to acknowledge the independence of Kosovo."29 It was emphasized that the government undertook the only possible decision taking into consideration both membership in the EU and international commitments of Poland as well as understanding for the independence of Kosovo aspirations. In the opinion of the chief of the Polish Peasants' Party Mr. Stanisław Żelichowski the decision of Minister Sikorski was right, however, as he stated "Poland does not have the obligation to appear in the front line." 30

Opposition politicians warned against to soon acknowledgement of the independence of Kosovo. In spite of the fact that the government of Poland supported the independence of Kosovo, Leftists and Democrats as well as Peace and Justice Parties appealed not to take any hasty decision. The opposition parties' disapproval of the government's decision had a negative impact on the evaluation of the government including its implemented foreign policy. Significant differences concerning that character and the way of Polish foreign policy implementation appearing between

${ }^{28}$ J. Bielecki, Premier Tusk: Kosovo as an Independent Country, "Dziennik”, 26.02.2008; Poland Acknowledges the Independence of Kosovo, "Gazeta Wyborcza", 26.02.2008.

${ }_{29}$ Polish Government Officially Acknowledged the Independence of Kosovo, http://www. tvn24.pl/-1,1540201,wiadmosc.html

${ }^{30}$ Today Poland Can Acknowledge the Independence of Kosovo, www.newsweek.pl/artykuly/ artykul.asp?Artykul=22634 
the Civic Platform and Peace and Justice Party formed an occasion for criticizing the operation of the government. The chairman of the Peace and Justice Party, Mr. Jarosław Kaczyński considered the Kosovo issue as complicated, because "independence of this province from Serbia may result in a subsequent conflict on the Balkans", and the government should not reach any hasty decision on that issue. Simultaneously, he criticized the government's policy severely by stating that "unfortunately Polish foreign policy is implemented by people who lack basic knowledge." ${ }^{31}$

The opposition pointed out to the need of analyzing the situation and selecting a proper moment. It did not reject the idea of acknowledging the independence of Kosovo and referred to this act as "historical justice", however, it insisted on not making any premature decisions. The opposition warned against stepping before the line and expected the government to withhold its decision until the situation is stable. Main focus was put on consequences of acknowledging the independence of Kosovo in respect to relations with Serbia and Serbian community. Mr. Karol Karski suggested withholding the decision for 2-3 months until the situation is cleared out. In his opinion, acknowledging of independence of Kosovo could be perceived by Serbia as integration in its internal affairs ${ }^{32}$. Acknowledgement of the independence of Kosovo in his opinion was premature as it did not reflect the "factual or legal state." ${ }^{33}$ The Peace and Justice politician was also against sending a Polish mission as from the point of view of the Balkan countries only an international organization could send such a mission ${ }^{34}$. Similarly, Mr. Paweł Kowal warned against too hasty acknowledging of the independence of Kosovo. In his opinion the Kosovo issue required a deep analysis and not a radical action. He emphasized at the same time that solidarity with other EU countries over the question of Kosovo formed an important aspect. He admitted hat there was no other alternative than to acknowledge the independence of Kosovo. ${ }^{35}$

Leftist politicians were very cautious to express their opinions. They did not criticize acknowledgement of the independence of Kosovo but rather pointed out to actions undertaken by the government at that occasion. Chief of Democratic LeftWing Alliance, Mr. Wojciech Olejniczak expressed the opinion that acknowledgement of the independence of Kosovo should be proceeded by an internal debate. Both him

${ }^{31}$ Acknowledgement of the KosovoIndependence Is Complicated, http://wiadomosci.onet. pl/1697023,11,uznanie_niepodleglosci_kosowa_jest_skomplokowane.

32 "Kosovo is Not a State", http://www.tvn24.pl/-1540227,wiadomosc.html

${ }_{33}$ Poland Acknowledges the Independence of Kosovo, http://www.newsweek.pl/artykuly/ artykul.asp? Artykul=22855

34 "Kosovo is Not a State", op.cit.

${ }^{35}$ Kosowo Disagreement - an Interview with an MP, Mr. Paweł Zalewski, http://www.psz. $\mathrm{pl} /$ content/view/9786/ 
and leftist politicians emphasized the need to undertake appropriate actions to ensure security of Serbian minority in Kosovo and guarantee observing their rights on the territory of the new country. For that purpose, in his opinion, Poland should increase pressure on the EU so that it would undertake necessary actions. Polish diplomacy, in the opinion of chief of Democratic Left-Wing Alliance was not effective in that respect. He criticized the fact that the government had not sent a representative to the Balkans who would get acquainted with the situation on site. For the leftist leader it was the evidence that the regime of Mr. Donald Tusk disregarded the problem "being convinced of its alleged success the government ignored the most important event taking place on the international arena." ${ }^{36}$

Similarly, Mr. Jerzy Szmajdziński accused the government of the lack of professionalism. In his opinion the government of Poland should be concerned with relations with Serbia, formulate conditions concerning minority rights and implementation of the European program the purpose of which should be integration of the Balkan countries with the EU. ${ }^{37} \mathrm{Mr}$. Tadeusz Iwiński, other leftist politician was one of the politicians who believed that there was no need for Poland to support the independence of Kosovo as one of the first countries. He stated that "Kosovo's neighboring countries should express their opinions on the Kosovo issue first", whereas Poland should analyze this question deeply and provide its opinion at a later date. Supporting the decision of the government on postponing the resolution on independence he criticized the government for its defensive operation. Similarly, as other leftist politicians he was for sending diplomatic representatives to Priština and Belgrade.

In his opinion, the government's decision would be a proof of carrying out independent and constructive politics free from any international pressure. ${ }^{38}$

The criticism of the government's actions by the left wing politicians was wellbalanced and did not concern the legitimacy of the acknowledgement of Kosovo's independence as far as the decision-making and its circumstances were concerned. Whereas the left wing politicians contested the haste when making the decision, politicians of the League of Polish Families, being at the margin of the Polish political scene, formulated very radical opinions about Kosovo's secession. They regarded the act of independence as a contradictory breach of the international law and harming Serbia's independence. The League of Polish families expressed their objections to the acknowledgement of Kosowo as an independent state and they saw the act as

${ }^{36}$ Olejniczak: Discredit for Diplomation for the Kosovo Issue, http://news.money.pl/artykul/olejniczak;blamaz;dyplomacji;ws;kosowa,219,0,323803.html

37 The Polish Government Officially Acknowledged the Independence of Kosovo, http://www. tvn24.pl/0,1540201,wiadomosc.html

${ }_{38}$ Today Poland Acknowledged the Independence of Kosovo, op.cit. 
a warning of danger looming over Europe. In their opinion, the decision to acknowledge Kosovo's independence was an example of interference into other territorial integrity of an independent country, which Serbia was. The party appealed that Poland should take the same position as Spain, Slovakia or Cyprus, all critical of Kosovo's independence. In its statement voiced before the formal announcement of the independence by Kosovo and just after the approval of financial and legal frames of the EU mission by the EU, the party's Main Board, February 9 2008, expressed its "deepest concern at the position of the Polish Ministry of Foreign Affairs supporting Kosovo's independence." ${ }^{39}$

Mr. Wojciech Wierzejski deemed the decision made by the government led by Donald Tusk as contradictory to strategic and national interests, being a part of the government's pro-German policy and he described it as one on the verge of "betrayal of the Polish interest." ${ }^{40} \mathrm{He}$ justified his criticism among others by citing the illegitimacy of Kosovos independence declaration in the light of the international law, posing danger to the existing international order, the establishment of another, Islamic state whose civilization was alien to Poland, involving Poland in the diplomatic game between the USA and Russia, making Poland responsible for the legitimisation of the partitioning of a Slavic state, an unlawful act breaching the country's right its independence and integrity. ${ }^{41}$ Another politician of the Party, Mr. Mirosław Orzechowski, considered the Polish decision to acknowledge Kosovo's independence "a disgrace breaching the international law, contradictory to Polish interests, inspired by foreign forces ruling Europe". The criticism of the government's decision derived from the party's declaration on Kosovo's independence. The party described Kosovo's secession as "the first attempt in the $21^{\text {st }}$ century to carry out a partition of a European country having its roots deep in the Christian culture", carrying serious political and economic consequences to Poland, the Balkans and whole Europe ${ }^{42}$. Expressing their protest against Kosovo's secession and supporting Serbia and the Serbian nation, they organized a demonstration in Warsaw. Carrying banners supporting Serbia "Belgrade - Warsaw, common cause!", "Serbs, we support you" and banners condemning Tusk's government and Lech Kaczyński, who did nothing to help Serbia, "Disgrace!", "Brussels servants!", they claimed that by organizing the demonstration

39 Press announcement: The League of Polish Families is Against Supporting the Independence of Serbian Kosovo by the EU, http://www.lpr.pl/?sr=!szukaj\&id=6268\&dz=kra$\mathrm{j} \& \mathrm{x}=7 \& \mathrm{q}=$ Kosowo $\& \mathrm{pocz}=0$

${ }^{40}$ Dispute on Kosovo Issue: "Good", or "Hasty" Decision?, http://wiadomosci.onet.pl/ 1699704,11,1,1,item.html

${ }^{41} \mathrm{http}: / /$ wiadomosci.onet.pl/blogi/wierzejski.blog.onet.pl,297248493,blog.html

${ }^{42} \mathrm{http} / / /$ wiadomosci.onet.pl/blogi/miroslaw-orzechowski.blog.onet.pl,297193161, blog.html 
the party "expressed its opposition to EU and USA's interference in Serbia's affairs." ${ }^{3}$

Mr. Andrzej Lepper not present in the Polish political scene criticized the Prime Minister for his attitude to the question of Kosovo and he advised caution and withholding from undertaking any final and binding actions as he was afraid that "acknowledging the independence of Kosovo may result in a war in the Balkan Peninsula." ${ }^{44}$ Mr. Piotr Ikonowicz a representative of the Self-defence Party in the last elections mentioned "district division of Europe". He defined the decision of the Polish government as forced by the commitments stemming from the membership in the Alliance. "The face of the Prime Minister reflected the fact that he was acquainted with surveys and he was aware that Poles supported Serbia and elementary justice. I have a feeling that we are doing something dirty to the Serbs and nothing good for Kosovians, who without economic relations with Serbia will become dependent on the western countries. ${ }^{45}$

The discussion that took place in Poland on the Kosovo's secession and proclamation of independence of this province reflects a general tendency of the Polish politics, that is using various external events as the subject for public debates to solve internal clashes. Observing political disputes we can have an impression that politicians forget about the main subject of the discussion and their opinions are dominated by political sympathies or antypathies. Unfortunately it is not the first time Polish debates were not based on an accurate evaluation of the situation, public analyses of consequences of acknowledging independence of Kosovo (no matter whether it took place directly after the proclamation of independence or several weeks later). Society was not informed about the motives of the government apart from the need to appear in the "European" policy tendencies. It shall be added, however, that the government had "no other options to select". No matter what decision would be reached it could be criticized anyway. If the government acknowledged the independence of Kosovo too soon its action would be evaluated as premature, whereas if it decided too late it

${ }^{43}$ A manifestation to express support for Serbia was organized, among others in Białystok and Warsaw. The organizer of the latter one was the Rightness of the Polish Left - Wing Party. See: Białystok: Manifestation to Support the Serbs, http://wiadomosci.gazeta.pl/Wiadomosci/1,80708,4966473.html; 150 Persons Manifested their Disapprobation of Acknowledging Kosovo as a Sovereign Country by the Polish Government, www.lpr.pl/?sr=!szukaj\&i$\mathrm{d}=6297 \& \mathrm{dz}=\mathrm{kraj} \& \mathrm{x}=2 \& \mathrm{q}=$ Kosowo\&pocz=0; Warszawa: Kosovo the Heart of Serbia, www. racja.org.pl/content/view/571/1/

${ }^{44}$ Lepper: Tusk Succeeds Only in Foreign Policy, http://miasta.gazeta.pl/lublin/1,35640, 4963102.html

${ }^{45}$ P. Ikonowicz, Districtal Division of Europe, www.samoobrona.org.pl/pages/09.\%20 Polemiki/index.php?document=/634.html 
could be accused of imitating the position of other countries or adopting a secure position and lack of solidarity with Kosovo. The example of Kosovo depicts the difficulty of diplomacy. However, we shall bear in mind that the decision made by the government would have an impact on future relations with Serbia and the new country. Poland, as the government emphasized was concerned about friendly relations with both countries. However, it was difficult to avoid the deterioration in relations with Serbia. Serbia's representative in Poland, having in mind the so far relations with Poland insisted on not acknowledging the Kosovo's secession pointing the to potential consequences for future relations. Additionally, the situation of Poles domiciled in Serbia could deteriorate. Thus, the ambassador of Poland in Serbia, Mr. Maciej Szymański applied to the Serbian authorities to increase security means to protect the Polish diplomatic post. This request stemmed from the increased threat which appeared after the Embassy of the United States located near the Polish diplomatic post was attacked.

The increase of the threat to security of Poles domiciles in Serbia or Polish servicemen stationing there results from the governments' decision to acknowledge the independence of Kosovo. However we cannot determine that the threat would be reduced if the government's decision was different. The operation of the country on the international scene is always related to the necessity to reach difficult decisions not always accepted by everybody. Poland as a country aspiring to play a significant role in Europe must undertake a commitment to involve in international affairs while simultaneously taking into consideration its potential and possibilities. 